\title{
Determinants of recognition of TRACES certification as valuable opportunity at the farm level in São Paulo, Brazil
}

\author{
Marcela de Mello Brandão Vinholis ${ }^{\mathrm{a} *}$, Hildo Meirelles de Souza Filho ${ }^{\mathrm{b}}$, Marcelo José Carrer ${ }^{\mathrm{b}}$, \\ Fabio Ribas Chaddadc \\ ${ }^{a}$ Empresa Brasileira de Pesquisa Agropecuária, São Carlos, SP, Brasil \\ bUniversidade Federal de São Carlos, São Carlos, SP, Brasil \\ 'University of Missouri, Columbia, Estados Unidos da América \\ *marcela.vinholis@embrapa.br
}

\begin{abstract}
TRACES (Trade Control and Expert System) is a veterinary health network created by the European Union to certify and monitor trade of animal products. This research aims to identify the factors that explain why few Brazilian farmers recognized adoption of the TRACES certification as a valuable opportunity. A farm is required to adopt traceability and a set of associated technologies to obtain certification. A sample of 84 beef cattle farms provided data for the testing of the hypotheses by means of a bivariate logit model. The recognition of the opportunity is positively correlated with previous experience with other quality programs, access to up-to-date information, a more diversified life experience, and active participation in relationship networks.
\end{abstract}

Keywords

Entrepreneurship. Traceability. Agriculture. Technology innovation. Beef cattle.

\section{Introduction}

Since the 90s, consumers, particularly in Europe, have attributed great importance to quality and food safety. To a large extent, this concern is associated with the increase in numbers of food contamination cases and the BSE (Bovine Spongiform Encephalopathy) crisis. In particular, the European Union (EU) has demanded traceability for beef and has created a set of directives for their trade partners (CE 820/97 and 178/2002) as conditions for access to its market. These events highlight the close interdependence among different stages of the production chain and the limitations of quality control along the food chain (Hobbs, 2004), as well as have fostered the diffusion of new legal rules and certification systems related to food safety and quality (Fulponi, 2006; Trienekens \& Zuurbier, 2008).

Brazil has one of the largest commercial cattle herds in the world. In 1998, Brazil exported around 370,000 tons of beef. In 2004, the country rose to the top of world exports with a fifth of the internationally sold meat. In 2012, it topped 1.8 million tons of exported beef (Brasil, 2010a). This increase was driven by the depreciation of the Brazilian currency beginning in 1999, as well as by the growing demand for meat on the international market. However, in order to maintain its large share of the market, the Brazilian beef industry faces challenges in order to cope with strict food safety standards. Brazilian authorities have introduced new food safety regulations.

In 2002, The Brazilian System of Identification and Certification of Bovine and Bubaline Origin (SISBOV) was created to meet European requirements for traceability. This system, based on voluntary adoption, is coordinated by the Ministry of Agriculture, which is responsible for the approval of private third-party certification agencies. In 2011, SISBOV certification 
was a necessary though not sufficient condition to export beef to the EU. The farm had to register with the Trade Control and Expert System (TRACES). TRACES is a veterinary health network created by the EU to notify, certify and monitor trade in animals and animal products. This requirement was created in 2008 by the EU authorities, which had to approve SISBOV certified farms and register them on the TRACES list. In 2012, this duty was assumed by the Brazilian Ministry of Agriculture. Since then, TRACES List has been named 'Third Country Bovine Holding List'. SISBOV/TRACES certified farms had to adopt traceability as well as a set of management and operational technologies.

Traceability is considered an innovation in Brazilian livestock. According to Audretsch et al. (2002), if an idea is perceived as new by an industry, it is an innovation, even if such a change may not be new for other industries. The implementation of traceability leads to the adoption of practices such as individual identification of animals, records of the animal's history, inventory control and the adoption of information technologies, such as software and electronic devices for cattle management (Nantes \& Machado, 2005; Cocaro \& Jesus, 2008). However, several years after its institutionalization, the level of dissemination is still low. In 2010, there were only 1,895 certified farms in TRACES, which represented 1.7\% of the cattle farms in Brazil with more than 50 head of cattle (Brasil, 2006). In the state of São Paulo, there were 137 certified farms, which represent $0.5 \%$ of the cattle farms in the state. Consequently, technological heterogeneity persists among livestock production in Brazil (Brasil, 2010b).

Brazil was a country capable of expanding its production of beef under the new conditions established by the EU, given its availability of land and other necessary resources. However, few Brazilian farmers have identified this opportunity. The aim of this empirical research is to identify factors that explain why few Brazilian farmers had recognized the adoption of SISBOV/TRACES certification as a valuable opportunity.

The identification and exploitation of opportunities are key processes and the main focus of current literature on entrepreneurship (Venkataraman, 1997; Shane \& Venkataraman, 2000; Shane, 2003; Baron \& Shane, 2007). In this literature, there are two theoretical strands regarding the emergence of opportunities. The first argues that opportunities emerge from changes in the world outside the individual. The second strand argues that opportunities are created by individuals. In either case, their materialization requires human action. Thus the question remains: why do some people recognize an opportunity as valuable while others do not? The model proposed by Baron \& Shane (2007) establishes a set of explanatory variables related to the characteristics of the individuals who stand out from the rest of society as entrepreneurs (Baron \& Shane, 2007; Shane, 2003), such as life experience, professional experience and relationship networks. A review of the literature is presented in order to generate hypotheses on the characteristics of farmers that could explain the adoption of SISBOV/TRACES certification as a valuable opportunity.

\section{Theoretical framework}

This section attempts to review the factors that are likely to influence the process of opportunity recognition. The literature on entrepreneurship provides a framework to understand why, when and how individuals identify a valuable opportunity. Entrepreneurship has been on the research agenda of various fields, but little emphasis has been placed upon characteristics of individuals (Knudson et al., 2004). For this reason, we regarded other sources of literature, such as management and psychology. Next section presents the definitions of entrepreneurship and its relation to valuable opportunities. Subsequently, a review of factors influencing the recognition of opportunities at the individual level is presented, which is the main focus of this article.

\subsection{Entrepreneurship and opportunity}

Despite there being a consensus in the literature of the importance of entrepreneurship for economic development, it is a phenomenon complex to understand. Studies in different fields are involved in building a theoretical framework to explain entrepreneurship. However, there is still no consensus regarding its definition (Baron \& Shane, 2007) and the object of analysis (Klein, 2008; Bruyat \& Julien, 2001). The literature review conducted by McElwee (2005) shows that entrepreneurship is a term used in many different ways, resulting in multiple interpretations (Wolf et al., 2007). The most commonly used definition is that entrepreneurism is an

[...] activity that involves the discovery, evaluation and exploitation of opportunities to introduce new products and services, forms of organization, markets, processes and raw material through previously nonexistent organizational efforts [...] (Shane, 2003, p. 4; Shane \& Venkataraman, 2000; Venkataraman, 1997).

The exploitation of a new opportunity does not necessarily require the creation of a new company. The resources necessary for the exploitation of an 
opportunity can be organized by means of organizational arrangements other than a company or by means of a market mechanism (Shane, 2003; Xue \& Klein, 2010). The entrepreneur is the individual responsible for the process of creating new value through an innovation and/or a new organization (Bruyat \& Julien, 2001).

In agriculture, the vast majority of rural producers own their business. To a large extent, it is a business passed down from generation to generation. However, farmers can be entrepreneurs in the sense that they respond to changing conditions by reallocating production resources (Yang \& An, 2002). Under certain conditions, they introduce technologies that change the form of production and create new organizational arrangements for the commercialization of their products, without necessarily creating a new company. According to Wolf et al. (2007), agricultural entrepreneurship is connected with finding ways and means to create and develop a profitable farm business. Thus, the concept of 'entrepreneurship' can be used to explain the phenomenon of value creation within new or existing businesses in agriculture.

Based on this more comprehensive definition, authors try to explain why, when and how opportunities for creating new value arise as well as why, when and how some individuals and not others discover, evaluate and acquire the resources to exploit them (Shane \& Venkataraman, 2000; Shane, 2003).

There is a current theory that claims that the market is in a constant state of disequilibrium and that opportunities are not waiting to be discovered by the entrepreneur, but are rather created by the entrepreneur (Chiles et al., 2007). In this view, opportunities arise in the mind of some individuals based on acquired knowledge and cognitive resources (Alvarez \& Barney, 2007). Another approach claims that opportunities exist independently of individuals or firms (Shane, 2000; Shane \& Venkataraman, 2000). Potentially valuable opportunities are the result of changes in the outside world. The sources of opportunities can be technological, social, demographic, economic or institutional changes (Baron \& Shane, 2007). The existence of an opportunity is a necessary condition for the development of the entrepreneurial process (Shane, 2003; Eckhardt \& Shane, 2003), but not a sufficient one. The mere existence of an opportunity does not result in its exploitation. Opportunities are exploited only when a human action exists, in part, driven by profit (Hébert \& link, 1988). They remain as a potential until they are identified by specific human minds, as a result of active cognitive processes (Baron \& Shane, 2007). Bruyat \& Julien (2001) suggest that the intersection between opportunities and enterprising individuals or mode of organizing, or both, is central to entrepreneurship theory.
Regardless of which approach leads to the emergence of opportunities, it is plausible to state that even an opportunity generated by changes in an environment outside the realm of the individual requires human action to make it into a reality. Yet, the question raised by Baron \& Shane (2007) remains: why do some people recognize an opportunity as valuable while others do not? The authors consider two complementary dimensions in the analysis. The first has to do with environmental factors, which are capable of molding the behavior and the decisions of individuals. The second has to do with the characteristics of enterprising individuals, which stand out from the rest of society (Baron \& Shane, 2007; Shane, 2003). The focus of the analysis and empirical investigation of the present article deals with the latter dimension, which shall be addressed in more detail in the next section.

\subsection{Individual factors influencing the recognition of opportunity}

With regard to individual factors, Shane (2003) assumes that there are differences between people. In the absence of these differences, anyone could recognize an opportunity and act on it, making the existence of superior profit impossible (Hébert \& Link, 1988). Baron \& Shane (2007) suggest that information plays a central role in the process of distinguishing between opportunities that are potentially valuable and others of less value and in the capacity of individuals to exploit them economically. What makes a person more apt than another to recognize a good opportunity is having better access to certain types of information and being able to use this information effectively (Baron \& Shane, 2007; Baron, 2007).

Based on a cognitive approach, Baron \& Shane (2007) suggest that the stock of knowledge or the experience of an individual is the raw material for the process of recognizing an opportunity. The process of discovery can be driven by recognition of knowledge already possessed rather than by a search for knowledge needed. Consequently, individuals who have developed particular knowledge through education and experience will be more likely to discover particular entrepreneurial opportunities in response to a given change (Shane, 2000). Studies in agriculture have highlighted the importance of education in developing this capacity (Lacky, 1999). In the theory of human capital, Schultz (1975) showed the positive effect of the level of formal education on the ability of individuals to perceive and react to opportunities resulting from a situation of market disequilibrium. 
The knowledge acquired through education and experience is stored in the human mind in an organized manner. Cohen \& Levinthal (1990) suggest that new information is recorded in memory through links or associations with pre-existing knowledge. This knowledge is grouped by means of concepts or "mental paths". In order to create something new or identify an opportunity it is necessary to break these paths and perceive previously unnoticed similarities. The concepts are expanded, combined and associated using analogies through active cognitive processes. The more organized and developed the mental structure of the individual, the greater their chances of recognizing opportunities from a specific domain. Therefore, forms that enable expansion of an individual's knowledge base play a fundamental role in this process (Baron, 2007).

In addition to education, Hébert \& Link (1988) suggest that experience induces reflection, interpretation, discoveries and generalizations by individuals. Previous experience and/or knowledge acquired in a field related to the new technology are factors that influence behavioral variables, such as self-efficacy and anxiety with regard to the use of innovation. The concept of self-efficacy refers to the belief of the individual that he is capable of completing a specific task, given the circumstances. Self-efficacy is built to a large extent through previous experiences and has an indirect effect on the adoption of innovation. People with high self-efficacy present less anxiety with regard to the use of innovation (Bandura, 1997; Czaja et al., 2006). Therefore, individuals that have high levels of self-efficacy have a greater chance of being an entrepreneur (Markman et al., 2002).

Economic viability and effective introduction of new agricultural technology require a management process that is not based on pure mastery of knowledge and traditional practices of cultivation and cattle raising. In addition to previous experience on the subject of the new technology, Rahm \& Huffman (1984), Cohen \& Levinthal (1990), Baron \& Shane (2007) and Hartog et al. (2010) suggest that diversified professional experience and activities that provide access to "up-to-date" information increase one's knowledge base. For an individual to be creative, a broad knowledge base is essential. Cohen \& Levinthal (1990) argue that the ability to assimilate and make use of new information is a pre-existing function of knowledge. Knowledge is cumulative and the more knowledge related to the new task, the better the performance. Therefore, diversity of knowledge plays an important role in this relationship. A broader and more diversified knowledge base increases the chance of new information being related to knowledge previously acquired.
Another way of expanding an individual's knowledge base is through diversified life experience. Living in different places (Baron \& Shane, 2007; Hartog et al., 2010), or cosmopolitan characteristics of the individual (Rogers, 1983), contributes for the increasing of his knowledge base. Individuals who travel more often to large urban centers and involve themselves in issues outside their local social systems are more exposed to novel information. Doyle et al. (2000) confirmed empirical evidence of this positive relationship. However, Glaeser et al. (2002) point out that moving to another location can have the opposite effect on the social relationship network, since this resource is specific to the local community.

In addition to formal education and experience, sharing of information through a broad social network contributes for increasing one's knowledge base (Baron \& Shane, 2007; Baron, 2007; Hartog et al., 2010). Information accessed through a social network contributes to recognition of opportunities. The use of information is associated with the mental structure developed through experience and education. The more developed the mental structure, the more individuals can benefit from information obtained through social networks (Baron, 2007). In addition to increasing knowledge, participating in social networks with people who have different educations and professions, with contrasting points of view, helps to develop flexible and open thinking and break with mental paths (Baron \& Shane, 2007).

The relationship network does not assume only one form. On the contrary, it presents itself in multiple forms. Some of them are highly formal, such as professional associations, with a president and payment of annual membership fees. Other forms can be extremely informal, such as groups of people who gather regularly for sporting activities. Both are social networks where reciprocity is developed and which allow for gains and access to relevant information (Putnam, 2001). Participation of farmers in social organizations can also provide advantages in the commercialization of products, for example, by gaining greater bargaining power for purchasing of inputs and sale of agricultural products.

A broad base of knowledge, associated with specific cognitive abilities and behavioral variables, can maximize recognition of opportunities (Baron \& Shane, 2007; Baron, 2007). The behavioral characteristics of the individual are part of the description of attributes that differentiate an entrepreneur. Access to these characteristics has contributed to an understanding of the process of recognition of opportunity and adoption of technology. However, due to the complexity in observing, measuring and interpreting the effects 
of these attributes, some are rarely explored in empirical studies.

Active pursuit of opportunities is a behavioral variable used by Baron \& Shane (2007) to explain the process of recognizing opportunity. However, it is hard to measure in practice. Some characteristics responsible for the formation of an individual's personality present similarities to these characteristics of entrepreneurs. The psychobiological model of personality developed by Cloninger et al. (1993) describes characteristics of individuals that are capable of explaining differences in behavior. One of these characteristics is the novelty seeking temperament. "Temperament is considered a biological predisposition which remains stable throughout development, mostly inherited and which is not modified by the learning process [...]" (Adan et al., 2009, p. 687). Novelty seeking measures impulsivity, which is hypothesized to reflect individual differences with respect to their incentive to approach or initiate a behavior in response to novelty, complexity or signals of reward (Gonçalves \& Cloninger, 2010; Adan et al., 2009). With the exception of the study by Ekelund et al. (2005), which used one of the characteristics of temperament to evaluate risk aversion and the entrepreneurship process, no other empirical study that explored these characteristics to explain the entrepreneurial process was found.

\section{Hypotheses, data and methods}

The method consisted of testing hypotheses with regard to the individual characteristics, of the farmers, capable of influencing the recognition of opportunity. In this section, we present the hypotheses and describe the data and statistical model used to perform the analysis.

\subsection{Hypotheses}

Considering the theoretical context described, six explanatory hypotheses were formulated with regard to farmer characteristics that seek to explain the adoption of SISBOV/TRACES certification as a valuable opportunity:

$\mathrm{H} 1$ : the higher the level of education of the individual, the greater the chance he will recognize the opportunity.

$\mathrm{H}$ 2: the more experience an individual has with the subject related to the opportunity, the greater the chance he will recognize the opportunity.

$\mathrm{H} 3$ : an individual involved in an activity that provides greater access to up-to-date information is more apt to recognize the opportunity.

$\mathrm{H} 4$ : an individual with more diversified life experience is more apt to recognize the opportunity.

H5: an individual who participates actively in relationship networks associated with the subject of the opportunity is more apt to recognize the opportunity.

H6: an individual who has greater incentive to approach or initiate a behavior in response to novelty (novelty seeking) is more apt to recognize the opportunity.

\subsection{Data}

The sample comprises cross-section data on 32 certified farms, which were randomly selected from a population of 137 certified and approved farms on the TRACES list for the state of São Paulo, Brazil, and 52 non-certified counterfactual farms (Table 1). The latter were selected from a list of non-certified

Table 1. Geographic distribution of the sample.

\begin{tabular}{|c|c|c|c|c|c|c|}
\hline \multirow{2}{*}{$\begin{array}{l}\text { Regions of São Paulo state } \\
\text { Araçatuba }\end{array}$} & \multicolumn{2}{|c|}{ SISBOV farms } & \multicolumn{2}{|c|}{ Sample of certified farms } & \multicolumn{2}{|c|}{ Sample of non certified farms } \\
\hline & 19 & $13.9 \%$ & 4 & $12.5 \%$ & 15 & $28.8 \%$ \\
\hline Assis & 4 & $2.9 \%$ & 0 & $0.0 \%$ & 1 & $1.9 \%$ \\
\hline Araraquara & 0 & $0.0 \%$ & 0 & $0.0 \%$ & 1 & $1.9 \%$ \\
\hline Bauru & 26 & $19.0 \%$ & 6 & $18.8 \%$ & 7 & $13.5 \%$ \\
\hline Campinas & 1 & $0.7 \%$ & 1 & $3.1 \%$ & 1 & $1.9 \%$ \\
\hline Macro Metropolitana Paulista & 2 & $1.5 \%$ & 1 & $3.1 \%$ & 0 & $0.0 \%$ \\
\hline Marília & 6 & $4.4 \%$ & 3 & $9.4 \%$ & 2 & $3.8 \%$ \\
\hline Piracibaba & 1 & $0.7 \%$ & 1 & $3.1 \%$ & 0 & $0.0 \%$ \\
\hline Presidente Prudente & 24 & $17.5 \%$ & 4 & $12.5 \%$ & 12 & $23.1 \%$ \\
\hline Ribeirão Preto & 12 & $8.8 \%$ & 5 & $15.6 \%$ & 8 & $15.4 \%$ \\
\hline São José do Rio Preto & 41 & $29.9 \%$ & 7 & $21.9 \%$ & 5 & $9.6 \%$ \\
\hline Vale do Paraíba Paulista & 1 & $0.7 \%$ & 0 & $0.0 \%$ & 0 & $0.0 \%$ \\
\hline TOTAL & 137 & & 32 & & 52 & \\
\hline
\end{tabular}

Font: Brasil (2010b) and survey data. 
farms which was obtained from records of farmers associations and rural unions. Three criteria were used in this selection: farms must be in the same region of the sample of certified farms; livestock must be the major economic activity on the farm; and the farm must perform the fattening phase of cattle raising (not exclusively). As stated in the SISBOV regulation, the cattle must stay for a minimum of 90 days in a zone qualified for export and 40 days in the last certified farm before slaughter. Thus, the great incentive for certification adoption is on the finishing phase of cattle raising.

All farms were visited during the period from February to August 2011. The interviews were carried out personally with the owner of the farm or the person responsible for the decision regarding certification. The average duration was of two hours.

\subsection{Logit model}

In order to verify whether the specific characteristics of certain individuals differentiate them from the rest of the population of farmers and that such characteristics prepare them to recognize a valuable opportunity, the estimation of a logit model was performed by using the software Statistica 11.0. Logistic regression model is a choice model often used when the outcome variable is an indicator of a qualitative choice (Greene, 1993; Hosmer \& Lemeshow, 2000). The values taken by the dependent variable are merely a coding for some qualitative outcome (Greene, 1993). The choice models have also been performed by other empirical analyses on entrepreneurship (Ekelund et al., 2005; Block et al., 2012). The variable to be "explained" is the dichotomous qualitative choice: recognition or non-recognition of SISBOV/TRACES certification as a valuable opportunity. The decision on whether or not to certify means the farmer recognized or did not recognize the adoption of the traceability system and the certification as a valuable opportunity. It may be assumed that the farmer weighs the marginal advantages and disadvantages of the certification. As the parameters of this decision are not usually observable, for each farmer $i$, it was defined a latent variable, $y^{*}$, as

$y_{i}^{*}=\beta^{\prime} X_{i}+u_{i} \quad i=1, \ldots, N$

where $X$ denotes a set of explanatory variables and $u_{i}$ is a random error component. The observed pattern of recognition can be described by a dummy variable, $y$, such that $y_{i}=1$ if farmer $i$ has recognized the opportunity as valuable and has adopted it, and $y_{i}=0$ if he/she has not recognized it. These observed values of $\mathrm{y}$ are related to $y^{*}$ as follows:

$$
\begin{aligned}
& y_{i}=1 \text { if } \quad y_{i}^{*}>0 \\
& y_{i}=0 \text { otherwise }
\end{aligned}
$$

The probability of a farmer with certain individual characteristics recognizing the opportunity and adopting SISBOV/TRACES certification is given by:

$$
\begin{aligned}
& \operatorname{Pr}(y=1)=F\left(\beta^{\prime} x_{i}\right) \\
& \operatorname{Pr}(y=0)=1-F\left(\beta^{\prime} x_{i}\right)
\end{aligned}
$$

The $\beta$ parameters reflect the impact of a change in $x$ on the probability of recognition of SISBOV/TRACES certification as a good opportunity in the state of São Paulo, Brazil. The probability model is represented by a regression:

$$
E(y \mid x)=0\left[1-F\left(\beta^{\prime} x_{i}\right)\right]+1\left[F\left(\beta^{\prime} x_{i}\right)\right]=F\left(\beta^{\prime} x_{i}\right)
$$

If the probability model is linear, i.e. $F(\beta x)=\beta^{\prime} x$, two problems affect the estimation. One is due to the heteroscedastic errors and the other is that it is not possible to restrict the probability estimation in the range $[0,1]$. For binary dependent variables, it is not recommended to apply usual methods of parameter estimation, under the risk of obtaining estimated values of the dependent variable negative or greater than one. This is inconsistent with the nature of the variable (Hoffman, 2002). There are specific methods to avoid this problem, such as the nonlinear models. According to Greene (1993), in order to provide consistent estimates in model (5), it is expected that:

$$
\begin{aligned}
& \lim _{\beta^{\prime} x \rightarrow+\infty} \operatorname{Pr}(y=1)=1 \\
& \lim _{\beta^{\prime} x \rightarrow-\infty} \operatorname{Pr}(y=1)=1
\end{aligned}
$$

These conditions are satisfied if $F$ is a logistic distribution function:

$$
E(y \mid x)=\operatorname{Pr}(y=1)=F\left(\beta^{\prime} x\right)=\frac{e^{\beta^{\prime} x}}{1+e^{\beta^{\prime} x}}
$$

The dependent variable in the logit model is the natural logarithm of the probability of being in a group (certified farms) divided by the probability of being in the other group (non-certified farms). Using maximum likelihood procedures, estimates of the $\beta$ parameters are obtained. The goal is to find the best combination of independent variables that maximize the likelihood of obtaining the observed frequencies in both groups. The set of quantitative and qualitative (dummies) variables can be used in the model.

The estimated coefficients $\left(\hat{\beta}_{i}\right)$ of the logistic model should be interpreted as the variation of the natural logarithm of the odds ratio of recognition 
and non-recognition of opportunity, or adoption and non-adoption. Therefore, if a coefficient has a value $\hat{\beta}_{i}$, that is the value of the variation in the natural logarithm of the odds ratio caused by increasing one unit in the variable $x_{i}$, assuming fixed values for all other variables (ceteris paribus). Coefficient with negative sign means a reduction in the likelihood of adoption when changing the variable.

\subsection{Construction of variables}

In this section, the set of variables used to carry out the hypothesis tests using the logit model is presented.

\subsubsection{Dependent variable}

Recognition of the valuable opportunity by the individual is determined by the adoption of the SISBOV/TRACES certification and the set of associated technologies, which include: individual identification of the cattle herd by means of electronic devices; software for electronic inventory control and transmission of information to a national database; and monitoring and periodic auditing of the process. This set of practices constitutes an innovation for the Brazilian livestock raising industry, generally unaccustomed to electronic control of internal activities. The adoption of these practices is mandatory for farm certification. This certification is mandatory to export beef to the EU. However, the decision to apply for this certification by the farmer is voluntary. Therefore, only some individuals identified this opportunity as valuable and submitted themselves to the certification process. A binary dependent variable was created: if the respondent has a farm certified for export to the EU he receives a 1, otherwise 0 .

\subsubsection{Explanatory variables}

Information plays a central role in the process of recognizing a valuable opportunity. In the model described by Baron \& Shane (2007), this process is highly influenced by two factors related to the characteristics of the individuals: access to information and the capacity to use them. A survey questionnaire was used to get information on: access to key information, life and job experience, relationship network, novelty seeking behavior and capacity to use information. For each of the individual attributes a proxy was constructed (Table 2).

Level of education was used as a proxy for the capacity to use information stored by the individual (cattle farmers with undergraduate education $=1$, otherwise $=0$ ). This variable aids in increasing the knowledge base of the individual and in his capacity to interpret and use the knowledge acquired. A review of the literature indicated that the higher the level of education of the individual, that is, the more formal knowledge he possesses, the greater the chance he would recognize a valuable opportunity. Therefore, it is expected that the cattle farmers that have a higher levels of education are more likely to have recognized the adoption of the SISBOV/TRACES certification as a valuable opportunity.

An expanded knowledge base is an important prerequisite for recognizing and exploiting potentially valuable opportunities. More cosmopolitan individuals

Table 2. Description of explanatory variables.

\begin{tabular}{|c|c|c|}
\hline Characteristic of the individual & Proxy/variable & Hypotheses \\
\hline $\begin{array}{l}\text { Capacity to use stored } \\
\text { information }\end{array}$ & Schooling (H1) - Level of education & $\begin{array}{l}\text { The higher the level of education, the greater the knowledge } \\
\text { base and the capacity to use stored information, which gives the } \\
\text { individual a greater chance of recognizing a valuable opportunity. }\end{array}$ \\
\hline $\begin{array}{l}\text { Previous experience with the } \\
\text { subject of the opportunity }\end{array}$ & $\begin{array}{l}\text { Certification experience }(\mathrm{H} 2) \text { - } \\
\text { previous experience with other } \\
\text { certifications and quality practices }\end{array}$ & $\begin{array}{l}\text { Individuals with previous experience in other certifications or quality } \\
\text { practices, such as GlobalGap, show a greater chance of recognizing } \\
\text { a valuable opportunity. }\end{array}$ \\
\hline $\begin{array}{l}\text { Access to the up-to-date } \\
\text { information }\end{array}$ & $\begin{array}{l}\text { Agricultural newsletter }(\mathrm{H} 3) \text { - } \\
\text { paid specialized information and } \\
\text { accessed electronically }\end{array}$ & $\begin{array}{l}\text { Paid access to institutional and market information prepared by } \\
\text { consultants specialized in agriculture and livestock increases the } \\
\text { chances of recognizing a valuable opportunity. }\end{array}$ \\
\hline Diversified life experience & $\begin{array}{l}\text { Life experience }(\mathrm{H} 4) \text { - Living in } \\
\text { large urban areas for more than six } \\
\text { months and frequent international } \\
\text { business trips }\end{array}$ & $\begin{array}{l}\text { More cosmopolitan individuals who have access to international } \\
\text { market information have a broader and more diversified knowledge } \\
\text { base which contributes to increasing the chance of recognizing a } \\
\text { valuable opportunity. }\end{array}$ \\
\hline Broad network of relationships & $\begin{array}{l}\text { Relationship (H5) - Effective } \\
\text { participation in groups for cattle } \\
\text { farmers, formally and informally } \\
\text { organized }\end{array}$ & $\begin{array}{l}\text { The more farmers participate in relationship networks related } \\
\text { to livestock, the greater the chance of recognizing a valuable } \\
\text { opportunity. }\end{array}$ \\
\hline Active seeking for novelty & $\begin{array}{l}\text { Novelty seeking (H6) - Score } \\
\text { measured by the test TCl-56 } \\
\text { (Adan et al., 2009; 2010). }\end{array}$ & $\begin{array}{l}\text { The higher the score on the test, the greater the impulsiveness of } \\
\text { the individual for novelty and the higher the chance of recognizing } \\
\text { a valuable opportunity. }\end{array}$ \\
\hline
\end{tabular}


and those with varied life experience should present a broader knowledge base and more complex mental paths. This cognitive structure of the individuals serves as a guide for recognizing opportunity. Therefore, living in large urban centers for longer than six months and frequent international business trips were used as proxies for varied life experience (residing for a period of more than six months in cities with a population over 150,000 inhabitants or capitals and a high frequency of business trips abroad (at least once a year) $=1$, otherwise $=0$ ).

The literature reviewed indicates that previous experience related to the subject of the opportunity elevates self-efficacy by reducing anxiety regarding the opportunity. This variable is a facilitator in identifying the opportunity and how to move towards it. Therefore, it is expected that individuals with previous experience with other certifications, such as the GlobalGap, or previous experience with other quality tools as a result of participation in quality assurance programs coordinated by meat processing plants show a greater chance of recognizing the adoption of the SISBOV/TRACES certification as a valuable opportunity (previous experience with other certification and/or other quality assurance tools $=1$, otherwise $=0$ ).

The literature consulted shows that information plays an essential role in the process of recognizing opportunity. Formal or informal relationship networks are a way of accessing relevant information. Both membership and effective participation of the cattle farmer in professional associations and participation in informal groups are used as proxies for this variable. A positive impact of this variable is expected on the recognition of the adoption of SISBOV/TRACES certification as a valuable opportunity.

Another form of access to up-to-date information related to the subject of opportunity is through information disseminated by agricultural research institutes and specialized consulting companies. Access to paid electronic institutional and market newsletters is used as a proxy for access to up-to-date information (access to a paid newsletter in the field of study of the opportunity $=1$, otherwise $=0$ ).

Finally, active pursuit of opportunities is an important behavioral variable to explain the process of recognition of opportunity. This variable can be measured by the test provided and validated by Adan et al. (2009) and Adan et al. (2010). The Temperament and Character Inventory (TCl-56) test consist of 56 statements to measure four dimensions of temperament and three dimensions of character (Adan et al., 2009; 2010). This test is a short version of the TCl-R test based on the psychobiological model of personality developed by Cloninger et al. (1993) to explain differences in behavior. The novelty seeking is one of the temperament dimensions. This dimension consists of eight statements that are assessed by the individual (the farmer, in this case) through a five-point likert answer scale ranging from 1 (definitively false) to 5 (definitively true). Thus, the variable can range from 8 to 40 . A positive relation between this variable and the chance of recognizing SISBOV/TRACES certification as an opportunity is expected.

\section{Results}

Descriptive statistics (mean, frequency and standard deviation) of the explanatory variables were initially calculated. Table 3 shows the mean for the continuous variable novelty seeking for the two sample groups. It was found that the mean of the variable novelty seeking is very close for both analysis groups. The student's t-test confirmed that the average value for this variable does not differentiate the two groups.

Table 4 shows the observed frequencies for the values of the dummy variables relationship, agricultural newsletter, certification experience, life experience and schooling. The testing of hypotheses for the comparison of the frequencies showed that there are significant differences between the two groups, at a $5 \%(\alpha=0.05)$ significance level, for these variables, except schooling. In fact, the level of education of individuals in the sample was high and showed little variability, which is understandable given the location of the sample. According to census data for farming in Brazil, the state of São Paulo has the highest proportion of cattle farmers with undergraduate degrees, when compared to other states (Brasil, 2006).

To control for the effects of multicollinearity in the logit model, the correlation matrix was calculated (Table 5). Also, univariate logistic regression models for each variable were estimated in order to verify the statistical significance of each one. The variables life

Table 3. Descriptive statistics for continuous variable.

\begin{tabular}{|c|c|c|c|c|c|c|c|c|c|c|c|}
\hline \multirow{2}{*}{ Variable } & \multicolumn{5}{|c|}{ Certified farms } & \multicolumn{5}{|c|}{ Non-certified farms } & \multirow{2}{*}{$\frac{\text { Student's t-tes }}{(\mathrm{p})}$} \\
\hline & $n$ & mean & $\max$. & $\min$. & s.d. & $\mathrm{n}$ & mean & $\max$. & $\min$. & s.d. & \\
\hline Novelty seeking* & 31 & 15.87 & 24 & 9 & 4.05 & 47 & 16.36 & 29 & 8 & 4.64 & 0.6324 \\
\hline
\end{tabular}

*Six individuals from the sample refused to answer questions for the variable novelty seeking. Source: Survey results. 
experience, certification experience and agricultural newsletter were statistically significant at $1 \%$ level. The variable relationship was significant at 5\% level. The variables schooling and novelty seeking were not significant at 5\% level, showing no evidence of multicollinearity.

The logit model was estimated with data from 78 individuals because six individuals refused to answer questions for the variable novelty seeking. The results of logistic regression analysis are displayed in Table 6. The likelihood ratio (LR) was used to test the hypothesis that all the slope coefficients in the logit model are zero. The restricted log likelihood value is -52.41 . The unrestricted log likelihood value is -38.09 . The LR test statistics are therefore 28.65. With 6 degrees of freedom, the critical value at the $5 \%$ significance level is 12.59 , and so the joint hypothesis that the coefficients on the full set of variables are all zero is rejected.

The results of the estimated parameters of the model for relationship, agricultural newsletter, certification experience and life experience are in agreement with the theory. These parameters had the expected sign and are at statistically significant levels of 5\% or 10\%. Thus, we can accept hypotheses 2, 3, 4 and 5.

Table 4. Descriptive statistics for dummy variables.

\begin{tabular}{|c|c|c|c|c|}
\hline \multirow{3}{*}{ Variable } & & Certified farms & Non-certified farms & \multirow{2}{*}{ Chi-square } \\
\hline & & $(n=32)$ & $(n=52)$ & \\
\hline & & Freq. (\%) & Freq. (\%) & (p) \\
\hline \multirow{2}{*}{ Relationship } & No & 75 & 96 & \multirow{2}{*}{0.0105} \\
\hline & Yes & 25 & 4 & \\
\hline \multirow{2}{*}{ Agricultural newsletter } & No & 47 & 81 & \multirow{2}{*}{0.0012} \\
\hline & Yes & 53 & 19 & \\
\hline \multirow{2}{*}{ Certification experience } & No & 63 & 94 & \multirow{2}{*}{0.0007} \\
\hline & Yes & 38 & 6 & \\
\hline \multirow{2}{*}{ Life experience } & No & 56 & 85 & \multirow{2}{*}{0.0089} \\
\hline & Yes & 44 & 15 & \\
\hline \multirow{2}{*}{ Schooling } & No & 6 & 23 & \multirow{2}{*}{0.0876} \\
\hline & Yes & 94 & 77 & \\
\hline
\end{tabular}

Note: Yates corrected Chi-square was performed for variables 'Relationship', 'Certification experience', 'Life experience' and 'Schooling' since expected frequency was below 10. Source: Survey results.

Table 5. Spearman correlation matrix.

\begin{tabular}{|c|c|c|c|c|c|c|c|c|}
\hline & $\mathrm{n}=78$ & 1 & 2 & 3 & 4 & 5 & 6 & 7 \\
\hline 1 & SISBOV/TRACES Certification & 1.00 & & & & & & \\
\hline 2 & Relationship & 0.32 & 1.00 & & & & & \\
\hline 3 & Agricultural newsletter & 0.35 & 0.22 & 1.00 & & & & \\
\hline 4 & Certification experience & 0.40 & 0.31 & 0.28 & 1.00 & & & \\
\hline 5 & Life experience & 0.31 & 0.20 & 0.17 & 0.15 & 1.00 & & \\
\hline 6 & Schooling & 0.22 & 0.16 & 0.17 & 0.21 & 0.27 & 1.00 & \\
\hline 7 & Novelty seeking & -0.04 & 0.28 & -0.03 & 0.04 & 0.15 & -0.13 & 1.00 \\
\hline
\end{tabular}

Source: Survey results.

Table 6. Logistic regression analysis.

\begin{tabular}{|c|c|c|c|c|}
\hline Number of obs $=78$ & & & \multicolumn{2}{|c|}{ Log-likelihood $=-38.09$} \\
\hline $\mathrm{Chi}^{2}=28.65$ & & & \multicolumn{2}{|c|}{ NagelKerke $R^{2}=0.42$} \\
\hline Variables & Estimate $(\beta)$ & Odds Ratio $\left(\mathrm{e}^{\beta}\right)$ & Std. Error. & $\mathrm{p}$ \\
\hline Intercept & 2.8448 & & 1.5329 & 0.0635 \\
\hline Relationship ${ }^{* *}$ & 1.0061 & 2.7349 & 0.6008 & 0.0940 \\
\hline Agricultural newsletter*** & 0.5497 & 1.7328 & 0.3043 & 0.0708 \\
\hline Certification experience $^{*}$ & 0.8085 & 2.2445 & 0.3967 & 0.0416 \\
\hline Life experience* & 0.6786 & 1.9712 & 0.3368 & 0.0439 \\
\hline Schooling & 0.0106 & 1.0106 & 0.4604 & 0.9816 \\
\hline Novelty seeking & -0.0968 & 0.9078 & 0.0724 & 0.1813 \\
\hline Correct prediction & & & & 74.26 \\
\hline
\end{tabular}

*Significant at 5\% level. **Significant at 10\% level. Source: Survey results. 
The odds ratio, a measure of association, was estimated for each variable. Since the explanation variables are dichotomous and they are coded as either zero or one, the odds ratio is $\mathrm{e}^{\beta}$ and it approximates how much more likely (or unlikely) it is the adoption of the SISBOV/TRACES certification to be present among those with $\mathrm{x}=1$ than among those with $x=0$ (Hosmer \& Lemeshow, 2000).

The results suggest that the recognition of SISBOV/TRACES certification as a good opportunity and its implementation is 2.2 times as likely to occur among farms with previous compliance with other certification or quality assurance programs, such as GlobalGap, than among those with no previous experience on certification, ceteris paribus. Some initiatives of cattle quality programs coordinated by either meat processing plants or farming organization increase farmers' experience on individual identification of cattle, documentation procedures and audits. The farmers reported the need of hands-on experience (learning by doing) for documentation procedures and audits for traceability implementation. Also, the interpretation and application on their own of the rules governing the certification program is not an easy task for those farmers who do not have prior experience with other certification or quality practices. The outcome of the variable for certification experience in this study confirms other empirical findings (SouzaMonteiro \& Caswell, 2009). Previous experience with other certification or quality practices boosts the farmer's confidence to take on other certifications and decreases the time between the preparation of the farm for cattle traceability and certification approval. Banterle \& Stranieri (2008) argue that the investment on the implementation of quality schemes depends mainly on the size of the firms and on the synergies obtainable by other quality certification schemes already introduced. Thus, a cattle farmer with previous experience with other certification and a larger herd has advantage. The literature has pointed to a correlation of the size of firms with other analysis variables. In the model here presented, there is an assumption that larger rural firms, for which herd size is proxy variable, have more opportunities to test new practices, such as traceability and certification, since they have easier access to credit and key information and are in better position to handle risk (Karshenas \& Stoneman, 1993; Souza Filho, 2001). In general, size is associated with economies of scale (Galliano \& Orozco, 2011) and presents significant correlation with other explanatory variables (Vicente, 2002; Souza Filho et al., 2011). The correlation between the herd size and the explanatory variables certification experience and agricultural newsletter was observed at a $1 \%$ significance level. In order to avoid multicollinearity, herd size was not included in the logit model estimation. The variables created to test the theoretical model of opportunity recognition proposed by Baron \& Shane (2007) were sustained in the model.

Annual frequency of business trips abroad and living in large urban areas for over six months, reflecting varied life experience and cosmopolitan characteristics to some extent, positively influence and almost doubles the chance of recognition of SISBOV/TRACES certification as a valuable opportunity, ceteris paribus. Living in large urban centers increases proximity to distribution and consumption, which increases the exposure of the individual to information related to consumer trends and new demands. Technical visits, promoted by suppliers of inputs, meat processing plants, government agencies, universities or associations, and international exhibitions for agriculture and livestock provide contact with importers and knowledge of trends and requirements for the European market. These business trips abroad also provide exposure to knowledge of novelties developed and applied in other producer markets that, if adapted to domestic conditions, could generate an opportunity.

The coefficient of the variable relationship is positive and significant for the recognition of SISBOV/TRACES certification as a good opportunity and for taking steps toward implementing it. This variable is composed of formal and informal relationship networks related to beef cattle. The result indicates that being a member of farming associations, that is, participating in meetings and events promoted by associations and participating in informal farming groups increases by 2.7 times the chance of recognizing the opportunity and taking steps toward implementing it, ceteris paribus. This may be explained by the advantages of being active in an association. For instance, members have easy access to training through seminars and conferences, key information and credit. Being a member of an informally organized farming group is also positive. The network members have access to vital information and, more importantly, they have greater bargaining power when acquiring inputs or selling cattle.

The positive and significant coefficient of the variable agricultural newsletter is consistent with expectations that individuals with access to information on the market and agricultural technology would have a greater chance of recognizing the opportunity. Access to key information via internet increases by $73 \%$ the chance of recognition of SISBOV/TRACES certification as a good opportunity, ceteris paribus. The availability of information through information technology is improving in some segments of agriculture, though more intensely in some regions 
of the country. This new technology affects the form of management of the rural property by facilitating the search, access, storage and dissemination of information, which improve decision-making conditions for the producer (Souza Filho et al., 2010). Various specialized consulting firms and agricultural research institutes sell analyses written by specialists on the market, new technologies, institutions and statistics on the sector through online newsletters. Access to this special information in real time contributes to increasing one's knowledge base and capacity to critically analyze and interpret the signs of change in the sector. These cattle farmers are therefore more apt to identify good opportunities.

Although the sign expected from the variable schooling is in line with this theory, it was not significant in the model and hypothesis one was not confirmed. In general, the sample presented a high level of education and little variability. Similarly, the variable novelty seeking was not significant in the model, and did not corroborate hypothesis six.

\section{Conclusion}

The certification of farm on a nationwide bovine traceability system, named SISBOV, is mandatory in order to export beef to the EU. However, the decision to apply for this certification is voluntary and only few farmers are certified. This certification implies the adoption of traceability and a set of management and operational technologies. Based on the assumption that the application for this certification is an opportunity generated by institutional change, this paper presents an empirical analysis on the characteristics, of individuals, that influence the recognition of an opportunity as valuable and its adoption. Hypotheses generated based on literature on entrepreneurship were tested using original survey data at farm level.

The analysis suggests that a higher probability of recognition of farm certification as a valuable opportunity and its adoption is associated with previous experience with other certification or quality assurance practices, cosmopolitan life experience and frequent business trip abroad, and access to key information through specialized agricultural newsletters. Membership and participation in farming association events and membership in informally organized groups of farmers also increase the likelihood of opportunity recognition.

These empirical results corroborate concepts on the theoretical model on opportunity recognition proposed by Baron \& Shane (2007). Active participation in a broad relationship networks, such as the farmers' groups formal and informally organized allows exchanging of experience, access to up-to-date information, and greater bargaining power. Experience is another important factor. On one hand, previous experience with topics related to the opportunity provides confidence and reduces the learning time for adoption; on the other hand, broad life experience enlarges the capacity for understanding of market as well as the individual's knowledge base. The certified farmers have a more cosmopolitan profile, as showed by their experience of living in large urban areas and traveling abroad to make business. These features allow for better information regarding consumers' needs, external markets and innovation. Previous experience with other certifications or quality assurance programs provides capabilities required by the SISBOV/TRACES certification. As a result, the start-up time and cost are reduced.

The result regarding the behavioral variable for pursuit of novelty did not corroborate the theoretical model. However, it is difficult to state that behavioral variables do not explain the recognition of valuable opportunity. In fact, one could argue that the proxy variable used, based on a psychometric test, may not have been appropriate for the subject. Therefore, we suggest the need for more research on the suitability of these tests or other proxies. The paper contributes to the literature on entrepreneurship by increasing the empirical evidence. The limitation of the study lies in data for a single region, which may limit the potential generalization of the results. However, they are useful for countries with great opportunities to improve agricultural performance.

\section{References}

Adan, A., Lachica, J., Caci, H., \& Natale, V. (2010). Circadian typology and temperament and character personality dimensions. Chronobiology International, 27(1), 181193. http://dx.doi.org/10.3109/07420520903398559. PMid:20205565.

Adan, A., Serra-Grabulosa, J. M., Caci, H., \& Natale, V. (2009). A reduced Temperament and Character Inventory (TCl-56): psychometric properties in a non-clinical sample. Personality and Individual Differences, 46(7), 687-692. http://dx.doi. org/10.1016/j.paid.2009.01.023.

Alvarez, S. A., \& Barney, J. B. (2007). Discovery and creation: alternative theories of entrepreneurial action. Strategic Entrepreneurship Journal, 1(1-2), 11-26. http://dx.doi. org/10.1002/sej.4.

Audretsch, D. B., Thurik, A. R., Verheul, 1., \& Wennekers, S. (2002). Entrepreneurship: determinants and policy in a European-US comparison. Boston: Kluwer Academic Publishers. http://dx.doi.org/10.1007/b109395.

Bandura, A. (1997). Self-efficacy: the exercise of control. New York: W. H. Freeman.

Banterle, A., \& Stranieri, S. (2008). Information, labelling, and vertical coordination: an analysis of the ltalian meat 
supply networks. Agribusiness, 24(3), 320-331. http:// dx.doi.org/10.1002/agr.20169.

Baron, R. A. (2007). Behavioral and cognitive factors in entrepreneurship: entrepreneurs as the active element in new venture creation. Strategic Entrepreneurship Journal, 1(1-2), 167-182. http://dx.doi.org/10.1002/sej.12.

Baron, R. A., \& Shane, S. A. (2007). Entrepreneurship: a process perspective. South-Western: Thomson.

Block, J., Thurik, R., van der Zwan, P., \& Walter, S. (2012). Business takeover or new venture? Individual or environmental determinants from a cross-country study. Entrepreneurship Theory and Practice, 37(5), 1099-1121. http://dx.doi. $\operatorname{org} / 10.1111 / \mathrm{j} .1540-6520.2012 .00521 . x$.

Brasil, Instituto Brasileiro de Geografia e Estatística - IBGE. (2006). 2006 Agricultural Census. Retrieved in June 2012, from http://www.ibge.gov.br/home/estatistica/economia/ agropecuaria/censoagro

Brasil, Ministério do Desenvolvimento, Indústria e Comércio Exterior. (2010a). DEPLA: Foreign Trade Statistics. Brasília. Retrieved in December 2010, from http://www.mdic.gov.br// sitio/interna/interna.php? area $=5 \&$ menu $=1955 \&$ refr $=608$

Brasil, Ministério da Agricultura, Pecuária e Abastecimento. (2010b). SISBOV: Brazilian System of Identification and Certification of Bovine and Bubaline Origin. Brasília. Retrieved in February/October 2010, from www.agricultura.gov.br

Bruyat, C., \& Julien, P. (2001). Defining the field of research in entrepreneurship. Journal of Business Venturing, 16(2), 165-180. http://dx.doi.org/10.1016/S0883-9026(99)00043-9.

Chiles, T. H., Bluedorn, A. C., \& Gupta, V. K. (2007). Beyond creative destruction and entrepreneurial discovery: a radical Austrian approach to entrepreneurship. Organization Studies, 28(4), 467-493. http://dx.doi.org/10.1177/0170840606067996.

Cloninger, C. R., Svrakic, D. M., \& Przybeck, T. R. (1993). A psychobiological model of temperament and character. Archives of General Psychiatry, 50(12), 975-990. http:// dx.doi.org/10.1001/archpsyc.1993.01820240059008. PMid:8250684.

Cocaro, H., \& Jesus, J. C. S. (2008). Casos sobre a rastreabilidade bovina em empresas rurais informatizadas: impactos gerenciais. In Proceedings of the 46th Brazilian Congress on Rural Economy, Rio Branco, Acre, Brazil.

Cohen, W. M., \& Levinthal, D. A. (1990). Absorptive capacity: a new perspective on learning and innovation. Administrative Science Quarterly, 35(1), 128-152. http:// dx.doi.org/10.2307/2393553.

Czaja, S. J., Charness, N., Fisk, A. D., Hertzog, C., Nair, S. N., Rogers, W. A., \& Sharit, J. (2006). Factors predicting the use of technology: findings from the Center for Research and Education on Aging and Technology Enhancement (CREATE). Psychology and Aging, 21(2), 333-352. http:// dx.doi.org/10.1037/0882-7974.21.2.333. PMid:16768579.

Doyle, D., Jolly, R., Hornbaker, R., Cross, T., King, R. P., Koller, E. F., Lazarus, W. F., \& Yeboah, A. (2000). Case studies of farmers' use of information systems. Review of Agricultural Economics, 22(2), 566-585. http://dx.doi. $\operatorname{org} / 10.1111 / 1058-7195.00039$.

Eckhardt, J. T., \& Shane, S. A. (2003). Opportunities and Entrepreneurship. Journal of Management, 29(3), 333349. http://dx.doi.org/10.1016/S0149-2063(02)00225-8.

Ekelund, J., Johansson, E., Järvelin, M., \& Lichtermann, D. (2005). Self-employment and risk aversion: evidence from psychological test data. Labour Economics, 12(5), 649-659. http://dx.doi.org/10.1016/j.labeco.2004.02.009.
Fulponi, L. (2006). Private voluntary standards in the food system: the perspective of major food retailers in OECD countries. Food Policy, 31(1), 1-13. http://dx.doi.org/10.1016/j. foodpol.2005.06.006.

Galliano, D., \& Orozco, L. (2011). The determinants of electronic traceability adoption: a firm-level analysis of French agribusiness. Agribusiness, 27(3), 379-397. http://dx.doi. org/10.1002/agr.20272.

Glaeser, E. L., Laibson, D., \& Sacerdote, B. (2002). An economic approach to social capital. The Economic Journal, 112(483), F437-F458. http://dx.doi.org/10.1111/1468-0297.00078.

Gonçalves, D. M., \& Cloninger, C. R. (2010). Validation and normative studies of the Brazilian Portuguese and American versions of the Temperament and Character Inventory Revised (TCl-R). Journal of Affective Disorders, 124(1-2), 126-133. http://dx.doi.org/10.1016/j.jad.2009.11.007. PMid:19942293.

Greene, W. H. (1993). Econometric analysis. New York: MacMillan.

Hartog, J., Praag, M. V., \& Sluis, J. V. D. (2010). If you are so smart, why aren't you an entrepreneur? Returns to cognitive and social ability: entrepreneurs versus employees. Journal of Economics \& Management Strategy, 19(4), 947-989. http://dx.doi.org/10.1111/j.1530-9134.2010.00274.x.

Hébert, R. F., \& Link, A. N. (1988). The entrepreneur: mainstream views and radical critique. New York: Praeger.

Hobbs, J. E. (2004). Information asymmetry and the role of traceability systems. Agribusiness, 20(4), 397-415. http:// dx.doi.org/10.1002/agr.20020.

Hoffman, R. (2002). Variável dependente binária: lógite e próbite (Série Didática, No. 1262) Piracicaba: USP/ESALQ.

Hosmer, D. W., \& Lemeshow, S. (2000). Applied logistic regression. New York: Wiley. http://dx.doi.org/10.1002/0471722146.

Karshenas, M., \& Stoneman, P. L. (1993). Rank, stock, order, and epidemic effects in the diffusion of new process technologies: an empirical model. The Rand Journal of Economics, 24(4), 503-528. http://dx.doi.org/10.2307/2555742.

Klein, P. G. (2008). Opportunity discovery, entrepreneurial action, and economic organization. Strategic Entrepreneurship Journal, 2(3), 175-190. http://dx.doi.org/10.1002/sej.50.

Knudson, W., Wysocki, A., Champagne, J., \& Peterson, H. C. (2004). Entrepreneurship and innovation in the agri-food system. American Journal of Agricultural Economics, 86(5), 1330-1336. http://dx.doi.org/10.1111/j.00029092.2004.00685.x.

Lacky, P. (1999). 0 que pedem os agricultores e o que podem os governos: mendigar dependência ou proporcionar emancipação? Cadernos de Ciência e Tecnologia, 16(2), 157-162.

Markman, G. D., Balkin, D. B., \& Baron, R. A. (2002). Inventors and new venture formation: the effects of general selfefficacy and regretful thinking. Entrepreneurship Theory and Practice, 27(2), 149-165. http://dx.doi.org/10.1111/15408520.00004

McElwee, G. (2005). Developing entrepreneurial skills in agriculture: a literature review on entrepreneurship in Agriculture. Berlin: Entrepreneurial Skills of Farmers.

Nantes, J. F. D., \& Machado, J. G. C. F. (2005). Segurança dos alimentos e rastreabilidade: o caso da carne bovina no Brasil. In M. 0. Batalha (Ed.), Gestão do agronegócio: textos selecionados (pp. 369-423). São Carlos: EdUFSCar.

Putnam, R. (2001). Social capital: measurement and consequences. Isuma: Canadian Journal of Policy Research, 2(1), 41-51. 
Rahm, M. R., \& Huffman, W. E. (1984). The adoption of reduced tillage: The role of human capital and other variables. American Journal of Agricultural Economics, 66(4), 405413. http://dx.doi.org/10.2307/1240918.

Rogers, E. M. (1983). Diffusion of innovations. New York: The Free Press.

Schultz, T. W. (1975). The value of the ability to deal with disequilibria. Journal of Economic Literature, 13(3), 827-846.

Shane, S. (2000). Prior knowledge and the discovery of entrepreneurial opportunities. Organization Science, 11(4), 448-469. http://dx.doi.org/10.1287/orsc.11.4.448.14602.

Shane, S. (2003). A general theory of entrepreneurship: the individual-opportunity nexus. Massachusetts: Edward Elgar Publishing. http://dx.doi.org/10.4337/9781781007990.

Shane, S., \& Venkataraman, S. (2000). The promise of entrepreneurship as a Field of research. Academy of Management Review, 25(1), 217-226. http://dx.doi. org/10.5465/AMR.2000.2791611.

Souza Filho, H. M. (2001). Desenvolvimento agrícola sustentável. In M. 0. Batalha (Ed.), Gestão agroindustrial (pp. 585-627). São Paulo: Atlas.

Souza Filho, H. M., Buainain, A. M., Silveira, J. M. F. J., \& Vinholis, M. M. B. (2011). Condicionantes da adoção de inovações tecnológicas na agricultura. Revista Cadernos de $C \& T, 28(1), 223-255$.

Souza Filho, H. M., Rosa, F. T., \& Vinholis, M. M. B. (2010). Análise da competitividade da cadeia produtiva da carne bovina do estado de São Paulo. Informaç̧ões Econômicas, 40(3), 16-28.

Souza-Monteiro, D. M., \& Caswell, J. A. (2009). Traceability adoption at the farm level: an empirical analysis of the Portuguese pear industry. Food Policy, 34(1), 94-101. http://dx.doi.org/10.1016/j.foodpol.2008.07.003.

Trienekens J., \& Zuurbier P. (2008). Quality and safety standards in the food industry, developments and challenges. International Journal of Production Economics, 113(1), 107-122. http://dx.doi.org/10.1016/j.ijpe.2007.02.050.

Venkataraman, S. (1997). The distinctive domain of entrepreneurship research in advance. In J. Katz \& R. Brockhaus (Eds.), Advances in entrepreneurship, firm emergence and growth (pp. 119-138). Greenwich: JAl Press.

Vicente, J. R. (2002). Pesquisa, adoção de tecnologia e eficiência na produção agrícola (Série Discussão). São Paulo: Apta.

Wolf, P., McElwee, G., \& Schoorlemmer, H. (2007). The European farm entrepreneur: a comparative perspective. International Journal of Entrepreneurship and Small Business, 4(6), 679-692. http://dx.doi.org/10.1504/1JESB.2007.014979.

Xue, J., \& Klein, P. G. (2010). Regional determinants of technology entrepreneurship. International Journal of Entrepreneurial Venturing, 1(3), 291-308. http://dx.doi. org/10.1504/1JEV.2010.030978.

Yang, D. T., \& An, M. Y. (2002). Human capital, entrepreneurship, and farm household earnings. Journal of Development Economics, 68(1), 65-88. http://dx.doi.org/10.1016/ S0304-3878(02)00006-8. 